and intensive knowledge of seeds and seed testing allowed him to build effectively and have left their mark on this Station as it exists to-day. The study of seeds and allied problems provided his main interest on the research side, and his book, "Farm and Garden Seeds", which is remarkable for the accuracy and beauty of its hundreds of illustrations of seeds drawn in black and white and for the attractive style of its writing, portrays him at his best. His appointment as chairman of the Research Committee of the International Seed Testing Association established his claim to international reputation. His ability was soon recognized by the rye-grass seedgrowing industry in Northern Ireland, and his loss will be keenly felt by all those engaged in seed production, who looked to him continually for good advice and wise counsel.

As professor of agricultural botany (1924), dean of the Faculty of Agriculture (1928) and senior technical research officer of the Ministry (1928)-which posts he occupied at the time of his death-S. P. Mercer will be remembered by colleagues and students alike for his width of vision as a teacher, for the conscientiousness of his effort to give sound advice and for his unfailing courtesy. He became dean of the Faculty within a few years of its formation, and during his tenure of this office he succeeded in establishing it on sound lines, and gained and retained the respect of all in so doing. His conspicuous services to agricultural education and research in Northern Ireland were marked by the award of the O.B.E. in 1943.

At the outbreak of war he undertook additional duties in connexion with the control of seed production and distribution in Northern Ireland, and here he was able to bring his knowledge and experience to bear in assuming his not inconsiderable share of "the war effort".

Mercer did not enjoy robust health; he worked under a handicap which few of us are asked to bear, and knowledge of this only serves to emphasize the greatness of his achievements. A lover of peace, prevented by indifferent health from fighting to secure that peace, artist and idealist as well as man of science, gentle and retiring of nature, blessed with constancy of affection, he would have achieved much more had the strength been his and had his span of life been longer. We, his colleagues, mourn the loss of a fine and ardent spirit, an upright and just man rightly disturbed on occasion by the blatant and consistent imperfections existing in our race and grieved at his powerlessness to do more to put wrongs right.

A. E. Muskett.

\section{Prof. Leo F. Goodwin}

WE record with regret the death of Lieut.-Colonel Leo Frank Goodwin, professor of chemical engineering at Queen's University, Kingston, Canada, on August 15 , at the age of sixty-six. He was the elder son of the late Oscar Guttmann, author of "The Manufacture of Explosives" and of "Monumenta Pulveris Pyrii". Prof. Goodwin received his engineering training at the City Guilds Central Technical College and then took his Ph.D. in chemistry at the University of Heidelberg. He was a member of the Institution of Chemical Engineers and of the Engineering Institute of Canada and a fellow of the Institute of Chemistry. He became assistant to Sir William Ramsay at University College and held an assistant professorship for some years at the City College,
New York, before taking up his chair at Queen's University. There he inaugurated the first comprehensive course in chemical engineering in the British Empire. An enthusiastic advocate of an under. graduate curriculum for chemical engineers, he probably turned out during the last thirty-five years a larger number of fully qualified and successful chemical engineers than the rest of the British Empire, exclusive of Canada.

His published work dealt mainly with large-scale chemical processes such as the manufacture of pulp for paper, acetone, causticizing and cement colouring, and he was employed as consultant to some of these industries.

Prof. Goodwin also had a distinguished military career, first in the squadron of the Inns of Court Rifles and then in the Princess of Wales Own Rifles, Canada, which he commanded for some years. In September 1914 he came to England with the lst Canadian Division and served with them in France and Flanders during the critical 1915 campaign. After the battle of Givenchy he was seconded for service with the Canadian Munitions Board and rendered valuable technical service to the British and Allied Governments.

During the present War, Prof. Goodwin again served the Canadian Government in a military and technical capacity, and latterly supervised a number of selected research students engaged on Government sponsored research work. There is little doubt that his early demise was hastened by a long period of overwork.

Prof. Goodwin leaves a widow well known as an artist under the name of Helen Sinclair and a daughter now in the Canadian W.A.A.F. He will be greatly missed by a wide circle of friends here and in America. R. Robertson.

\section{Dr. M. C. Mott-Smith}

Dr. Morton C. Motr-Smrth, writer in physics for Science Service, Washington, died on June 9 . $\mathrm{He}$ was sixty-six years old. Although he joined the staff of Science Service less than three years ago, he had completed since then two important fundamental texts in physics for use in high schools and by soldiers and adult civilians. Of one of these- "Fundamentals of Electricity"-more than 650,000 have been printed, including editions for the use of the American Army and a translation into Spanish.

Dr. Mott-Smith was born in Hawaii on November 26,1877 . He graduated from the Massachusetts Institute of Technology in electrical engineering and obtained, his Ph.D. in physies, philosophy and mathematics at the University of Halle, Germany. He was formerly professor of physics at Colby College and George Washington University.

WE regret to announce the following deaths:

Prof. J. C. W. Frazer, research professor of chemistry in Johns Hopkins University, on July 28, aged sixty-eight.

Sir John Jarmay, K.B.E., a director of Brunner, Mond and Co., Ltd., and of other chemical works, on August 22, aged eighty-seven.

Prof. D. E. Smith, emeritus professor of mathematics in Teachers College, Columbia University, on July 29, aged eighty-four.

Mr. H. F. Tomalin, formerly conservator of forests, Ceylon, on August 16, aged eighty-two. 